\title{
Köyde Bir Öğretim Lideri: Dilek Livaneli
}

\author{
Doç. Dr. Tuncay AKÇADAĞ* \\ Fatih Sultan Mehmet Üniversitesi, Eğitim Fakültesi, Üsküdar / İstanbul / Türkiye, \\ tuncayakcadag@gmail.com, ORCID: 0000-0002-9131-2039
}

\section{Öz}

Bu çalışma, Samsun ili, Çarşamba ilçesi Kumköyü ilkokulunda ve köyde hatırı sayılır pek çok iyileştirmeler yaparak sesini duyurmuş olan öğretmen Dilek Livaneli (DL)'nin başarı öyküsünü oluşturmaktadır. Köy öğretmenliği ülkenin sosyo-politik ve ekonomik gidişine bağlı olarak her ne kadar önemini yitiren bir görüntü içinde olsa da, köylerde görev yapan öğretmenlerin neleri nasıl yapacağına dair yapılmış bir program ve çalışma tarifi bulunmamaktadır. Çalışma, DL'nin köydeki öğretmenlik yaşantısında neleri nasıl yaptığını ortaya koyarak yaptıklarının analizini yapma, diğer öğretmenlere yol gösterici olma ve buradan hareketle "Genel olarak köydeki okullara, öğrencilere ve köylülere her öğretmenin kendi gayreti doğrultusunda yapabileceklerine dair bir çalışma düzeni oluşturulabilir mi?" sorusunu sordurma hedefini taş1maktadır. Çalışma, nitel araştırma kapsamı içinde yer almaktadır ve durum çalışması (case study) ile desenlenmiştir. Bu doğrultuda elde edilen bulgulardan çıkan en önemli sonuç, köy öğretmenliği, okulun fizikî bakımı, öğrencilerin akademik, kültürel, sosyal başarıları ve bedensel gelişimleri, köyün ve köylünün kendi bulunduğu şartlar içerisinde ekonomik, sosyal ve kültürel yeniliklere kavuşturulması çabalarının toplamı olduğu, DL örneğinde görüleceği gibi yapılan işlerin ancak içsel bir motivasyon ve bir çalışma düzeni ile sağlanacağı yönündedir.

*Sorumlu Yazar Tel: +90 2165218100 - 3033 
Anahtar Kelimeler: Köy öğretmenliği; Öğretim liderliği; Birleştirilmiş sınıflar; Dilek Livaneli.

\title{
An Instructional Leader in the Village: Dilek Livaneli
}

\begin{abstract}
This study constitutes the success story of Dilek Livaneli (DL) who became known through making respectable improvements in the Kumköyü Primary School which is located in Samsun province, Çarşamba district and the village itself. Although being a village teacher has a declining image which represents it lost its importance due to the country's socio-political and economic progress, there is not a program or working description for teachers working in villages to show them what to do and how to do. This work aim to analyze the experience of DL through revealing the things she did and the way she did, to guide other teachers and from this point of view, this work aims to make people ask the question of "Is it possible to prepare a working plan in order to render teachers capable so that they can accomplish necessary tasks related with people and students in villages on their own? This study is in the scope of qualitative study and its design is case study. The most important result is that village teacher, physical maintenance of school, student's academic, cultural, social achievements and physical developments mostly depend on the initiative taken by villagers' own economic, cultural and social attempts. As in the case of DL, success in such issues is related with inner motivation and work order of people's themselves.
\end{abstract}

Keywords: Village teacher; Instructional leadership; Combined classes; Dilek Livaneli.

\section{Extended Summary}

\section{Purpose}

Village children's education and village teacher is one of the educational problems in our country. Especially since the proclamation of Republic, various models are tried and solutions are thought to solve this problem. Village Institute is the best know one of these models. These institutions were established for the purpose of raising teacher, instructor and health officer for villages, and were established for the purpose of first reviving the 
village and then reconstructing the village, with its unique position and with its -in work, through work, and learning for work- method. Today, anxiety about being a village teacher and education in village still continues passing through various stages. Today education in the villages consist of combined classes accomplished via transportation from distant places. Its old name was "boarding primary schools" (YIBBO) and its new name is "boarding schools" (YBO). Combined class can be defined as a class which is formed by combining various grade classes as a result of the small number of students per grade and not being able to provide / not providing separate teachers for these grades and as a class which is under the direction of one teacher. Education given in these classes is defined as bringing together many classes and teaching them by one teacher. According to the experts, these schools are the most neglected schools. These schools are generally formed in economically disadvantaged areas and generally teachers who don't know how to work in village conditions are placed to these places. Despite the formation of a world increasingly urbanizing, it seems that schools with combined classes will remain for a long period of time. Although, combined classes are perceived as a problem, being a teacher in these classes can be turned into an opportunity with demand and effort. In our country, many success stories of teachers working in these places is being written and told. One of these teachers unlike her colleagues achieved to create a difference by systematically recording her successful practices done in combined class of the village and for the people living in the village. The aim of this study is to eloborate on the Turkish teacher DL's success in terms of expanding vision, motivation, working discipline and her struggles via analysis related with reasons and ways of her attempts.

\section{Method}

This study is a qualitative research and its design is case study. Case study is the investigation of a person, a place, a document and a case in detail. Data of the research is collected through interview with DL who is the subject of this case study. Interview was done through semi-structured interview form and interview was recorded. The other data collection tool is the written and visual documents in the media about DL. Data obtained through interview was compared with the written and visual documents in the media. In this way, the enrichment of database of the research was provided.

Data were analyzed through descriptive and systematic analysis 
method. Descriptive and systematic analysis method requires defining the methods such as wording of the speech text, classification of the answer in order to determine the obtained results in a more systematic way. Edited data is tried to be reported in a way that both readers will enjoy and there won't be unnecessary information.

\section{Result}

1. DL was raised by being given responsibility from an early age. Accordingly, DL has known the satisfaction of taking the responsibility of a work and accomplishing the task she has undertaken from an early age and she maintains this in her work life.

2. DL feels satisfied as a teacher. She is the part of enjoyment in learning environment with interiorising attitudes toward occupation. She regards that every responsibility belongs to her in school context.

3. Even though being a teacher as an occupation requires the same things in general sense, being a village teacher differs in some respect. To illustrate, this is necessary to accomplish the needs of village in terms of school's physical structure and needs of people in this context so that teacher can contribute to the development of villagers.

4. Education problems in combined classes may be reversed into an opportunity for the leadership abilities in children and learning synergy.

5. The issue of accomplishing the educational needs of children and villagegers' requirements are regarded as basic problems. Attempts to solve each problem give way to an opportunity for the resolvement of another problem. These connected attempts are called as projects.

6. Each step of solving problems was documented with photographs and videos. In the cases of needs, these documents were open to audience.....

7. There was an emergence of new working system based on the experiences of DL. The flow of such system was expressed as feeling and defining the problem-thinking about alternatives in order to solve the problem and deciding an one of them-searching and finding sources-organizing: defining roles, assigning-accomplishing activity; following the process step by step-gathering any data to present; 
taking photos of all activities-defining the name of activity, presentation in local, internal and international media, social media, meetings, congress vb.

\section{Discussion}

For the development of DL, there are effects of her mother and father beyond the being conscious parents: DL was the person who needed to serve many requirements of life on her own. She accomplished responsibilites of her own life as in the cases of many Anatolian children who are responsible for decreasing work load of family. As a result, such responsibility drived her to be a person who needs to design her own works and duties throughout the life. There is consistency between the situation and the statement of Cüceloğlu (2006) that children need to drive their own life while being aware of their own responsibilities for life.

The main reason for the success of DL as being a teacher may be attributed to her perspective rendering being a teacher satisfied herself and collaborates while designing work atmosphere in this sense. Feedback gathered from such kind of work discipline is expected to affect motivation positively. As Drucker (2006) pointed, people who work in their own qualified professional area with their own working styles have much more possibility to gather positive results. On the other hand, factors including eliminating dictation by someone else and interiorising occupation with contributing its design and implementation are the other factors behind the success.

There is consistancy between success of DL's experiences and the statement of Senge (1991) that getting better or worse is related with circular and spiral construction in system. Therefore, pros and cons have an effect on occurance of coming step as getting better or worse. It can be said that each positive step taken in villages contribute to the emergence of better spiral in a positive way.

\section{Giriş}

Cumhuriyet kurulduğu zaman genel nüfusun büyük çoğunluğunun köylerde yaşamaları nedeniyle bu yıllarda köylerde eğitimin nasıl olması gerektiği, eğitim sorununun merkezinde yer almaktaydı. Başta Amerikalı bilindik eğitimci John Dewey olmak üzere, bazı yabancı eğitimciler ülkeye davet edilerek bu sorunun çözümünde katkı getirmesi amacıyla incelemeler yapması istenmiştir. Bu eğitimcilerin sundukları raporlar ve yerli uzmanların 
görüşleri ortak bir noktada birleşmiş, 1937-1938'de açılan Köy Öğretmen okullarının köy koşulları ve ihtiyaçlarına göre yeniden düzenlenmesi önerilmiştir. Söz konusu saptamaların, tartışmaların, önerilerin doğrultusunda 17 Nisan 1940 günü 3803 sayılı yasa ile Köy Enstitüleri açılmış ve sayıları 21'e çıkarılmış ve 5-6 yıl içinde köyde görev yapmak üzere binlerce öğretmen yetiştirilmiştir (Binbaşığlu, 2010, s.375).

Köy Enstitülerini Kaplan ve arkadaşları, "Kendine özgü konumu, iş içinde, iş aracıliğıyla, iş için öğretme yöntemiyle; köye öğretmen, ĕgitmen ve sağlık memuru yetiştirmek, önce köyü canlandırmak ve sonra kalkındırmak için İ. Hakkı Tonguç'un geliştirdiği kurumlardır." biçiminde tanımlamaktadır (Kaplan, Oran, Metin, Güvendi ve Akgöl, 1993).

1924 tarihli Köy Kanununa göre nüfusu 2.000'e kadar olan yerleşme merkezlerine köy denilmektedir (Resmî Gazete, 1924, s.68). Köy topluluğu, genellikle geniş anlamda tarımla uğraşan toplum bütünü ile ilişkisi az ve koordine edilmemiş olan toplumsal çevreden çok doğal çevre ile ilişki içinde bulunan az sayıda ailelerden kurulu anamalcı düzen öncesi özellikleri gösteren az çok özel topluluk olarak tanımlanmaktadır (Türk Dil Kurumu, 1980). Gedikoğlu (1949), 1930’lu yıllarda Türk köylüsünü gelenekçi bir yapı gösteren, genellikle atasından gördüğünü yapan, onların gittiği yoldan giden, kısaca yeniliğe açık olmayan yapısal bir özellik göstermektedir biçiminde tanımlamaktadır.

Eğitim açısından bakıldığında o yıllardaki temel sorunun bu günde benzerlik taşıdığı söylenebilir. $O$ dönemde nüfusun çoğunluğunun köyde yaşamasına karşılık, yapılan eğitim çalışmalarının köy için yeterli olamaması, köyde görev yapacak öğretmenler ve bunların niteliğinin nasıl olması gerektiği en önemli tartışma konularındandır. $\mathrm{O}$ dönemde bu günde olduğu gibi öğretmenler, çeşitli nedenlerle köye gitmek istememekte, gidenler ise köye uyum sağlamakta zorluk çekmekteydiler. Bu temel sorundan dikkate alınarak gerçekleştirilen Köy Enstitüleri uygulaması, soruna yanıt oluşturduğundan başarılı olarak sayılmaktadır (Şeren, 1982).

Köy Enstitülerinin başarılı işler çıkarmasının temelinde, köyün ve köylünün sorunlarının iyi analiz edilmiş olması ve buna çözüm getirecek kadronun köyden şikâyet etmeyecek bir kaynaktan, yani köylünün içinden bulunması olduğu belirtilebilir. Köy Enstitüleri Kanunun 6. maddesi,

“Köy Enstitülerinden mezun ögretmenler tayin edildikleri köylerin her 
türlü ögretim ve eğitim işlerini görürler. Ziraat işlerinin fennî bir şekilde yapılması için bizzat meydana getirecekleri örnek tarla, bağ ve bahçe, atölye gibi tesislerle köylülere rehberlik eder ve köylülerin bunlardan istifade etmelerini temin ederler. Bu ögretmenlerin disiplin işlerinin ne suretle verileceği bir nizamname ile tayin edilir.” (Kültür Bakanlığ1, 1940)

biçiminde idi. Böylece yetiştirilen öğretmenler devletin eğitim hedeflerini gerçekleştiriyor, köylünün diğer sorunlarına çözüm getirebiliyor veya yol göstericilik yapabiliyordu.

Günümüzde köylerdeki eğitim, birleştirilmiş sınıflar, taşımalı eğitim, eski adıyla yatılı ilköğretim bölge okulu (YİBO), yeni adıyla yatılı bölge okulları (YBO) uygulamalarından oluşmaktadır. Bunlardan birleştirilmiş sınıf, bir sınıfa düşen öğrenci sayısının azlığı ve bu gibi sınıflara ayrı birer öğretmen verilmemesi/verilememesi nedeniyle birden çok sınıfın birleşmesinden oluşan ve tek bir öğretmenin yönetiminde bulunan sınıf (Oğuzkan, 1981) olarak belirtilmektedir. Burada yapılan öğretim ise birçok sınıfın bir araya getirilerek bir ögretmence yetiştirilmesi olarak tanımlanmaktadır (Aryal, Neupane, Laudari ve Bhattarai, 2003; Hargreaves, Montreo, Chau, Siblı ve Thanh, 2001; Köksal, 2005; Oğuzkan, 1981; Şahin, 2007). Yukarıda sıralanan uygulamaların ortak özelliği bir zorunluluktan dolayı oluşturulmalarıdır. Bu konuda Wolf ve Garcia (2000)'in görüşleri oldukça ilgi çekicidir. Bu görüşlere göre bu okullar en çok ihmal edilen okullardır. Bu okullar genellikle düşük gelirli bölgelerde oluşturulmuş ve buralara genellikle köy koşullarında nasıl çalışacağını bilmeyen öğretmenler görevlendirilmiştir. Gittikçe şehirleşen bir dünyanın oluşmasına rağmen birleştirilmiş sınıflı okullar daha uzun bir süre var olacaktır.

$\mathrm{Bu}$ durumda oluşturulan eğitim politikaları, zorunluluktan ve çaresizlikten dolayı oluşturulmuş bu yerlerden bir an önce kurtulma yönünde gerçekleşmektedir. Şahin (2016)'in belirttiği gibi Türkiye'de son dönemlerde birleştirilmiş sınıf uygulaması yapan okul sayısında yüzde 52, öğrenci sayısında yüzde 67, öğretmen sayısında ise yüzde 78 oranında bir azalma gerçekleşti. Bu sayısal azalma nedeniyle bu ülkede 8.457 köyde artık okul yok, öğretmen yok. O köylerde artık bayrak töreni yapılmıyor, milli marşımız söylenmiyor, 29 Ekim Cumhuriyet Bayramımız, 23 Nisan Ulusal Egemenlik ve Çocuk Bayramımız 8.457 köyde kutlanmıyor. Ayrıca taşımalı uygulamanın başladığı 1989-1990 eğitim öğretim yılını izleyen 22 yılda 120 trafik kazasında 48 öğrenci yaralanmış, 62 öğrenci ise hayatını kaybetmiştir. 
Birleştirilmiş sınıflı okulların kapatılması yasa gereği öğrenci sayısı 10'un altına düştüğünde gerçekleştirilmektedir. Bu nedenle kapatılan okullarla nelerden vazgeçildiği Şahin'in de belirttiği gibi açıktır. Oysa bu yöntem bir problem olarak değil bir firsat olarak görülebilir. Bu model kimi çağdaş ülkelerde eğitsel faydası düşünülerek uygulanan ve klasik sınıf öğretimine alternatif bir öğretim modeli olarak değerlendirilmektedir (Aksoy, 2008; Taşdemir, 2012).

Aslında sorun olarak algılanan birleştirilmiş sınıf ve bu sınıflarda öğretmen olmak istenildiğinde, çabalandığında bir firsata dönüştürülebilmektedir. Bu firsatların değerlendirilmisi öğretim liderliği anlayışı ile çalışma durumu ile örtüştüğü söylenebilir. Sheppard (1996), öğretim liderliği davranışlarını, amaç belirleme, amaçları duyurma, öğretimi denetleme, programı koordine etme ve yönetme, öğretim zamanını koruma, sürekli görünür olma, öğretmenleri özendirme, mesleki gelişimi sağlama, akademik standartları belirleme, öğrenmeyi özendirme, öğrenci ilerlemesini izleme, öğretimde bilgili olma, kaynak sağlama, plan yapma, model olma, personel sağlama, toplum ihtiyaçlarına cevap verme, öğrenci davranışlarından sorumlu olma, başkalarına danı̧̧ma ve iyi ilişkiler olarak kurma olarak belirtmiştir (akt; Gümüşeli, 2014, s.28).

Ülkemizde pek çok öğretmenin bu yerlerdeki başarı öyküleri söylenmekte, yazılmakta, anlatılmaktadır. Bu öğretmenlerden biri diğer meslektaşlarından farklı olarak görev yaptığı köyde birleştirilmiş sınıflı okulunda ve köylülere yönelik yaptığı başarılı çalışmaları sistemli bir biçimde kayıt altına almayı başararak fark yaratmıştır. Samsun ili, Çarşamba ilçesi Kumköyü ilkokulu öğretmeni Dilek Livaneli (DL)'nin bu biçimde gündeme gelmesi, okulunda ve köyünde geçekleştirdiği projeleri, Hint asıllı iş adamı Sunny Varkey'in eğitim alanında projeler geliştirmek amacıyla kurduğu ve onursal başkanlığını ABD eski Başkanı Bill Clinton'ın üstlendiği Varkey Gems Vakfı (Varkey GEMS Foundation) tarafından düzenlenen 'Küresel Öğretmen Ödülü Komitesi'ne (The Global Teacher Prize) sunması ve en iyi 50 öğretmen arasında yer alma başarısını göstermesi üzerinde önemle durulması gereken bir durum olarak düşünülmektedir.

Bu başarısından sonra Livaneli, hem Bakanlık, hem üniversiteler, hem çeşitli televizyon kanalları hem de özel pek çok kuruluşun dikkatini çekmiş, yapmış olduklarının başkalarına örnek olması ve ondan ilham alınması için konuşmacı olarak davetler almıştır. Söz gelimi 24 Kasım 2012 tarihinde Millî 
Eğitim Bakanlığı tarafından Samsun'un “Mesleğinde Fark Yaratan Öğretmeni” seçilip Samsun'u Ankara'da TBMM, Başbakanlık ve Cumhurbaşkanlığı Köşkü'nde yılın öğretmeni unvanıyla temsil etmiştir. Böylece DL, çalışmalarına daha da hız vererek okulunda, çalışmakta olduğu köye ve aynı ortamı paylaştığı köylülere yönelik pek çok çalışmalar gerçekleştirmiştir.

$\mathrm{Bu}$ çalışmanın amacı, imkânları oldukça kısıtlı bir köy ilkokulunda öğrencilerin, köylülerin ve okulunun fiziksel bileşenlerini çeşitli projelerle etkilemeyi ve değiştirmeyi sağlayarak, bir başarı öyküsü oluşturmuş olan, DL'nin vizyon oluşturma, motivasyon, çalışma disiplini ve mücadele etme açılarından yaptıklarının analizini (niçin, nasıl, ne şekilde) yapmaktır. $\mathrm{Bu}$ çalışma ile:

1. Durumun bilinen ve bilinmeyen yönleri ile derinlemesine açığa ç1karılmas1,

2. Olgu ve olaylara aktörlerin bakışının belirlenmesi,

3. Olayların kurgulanışındaki örüntülerin anlaşılması,

4. Olgular ve olaylar üzerinden yorumların yapılması,

5. Durum ile ilgili hipotezlerin geliştirilmesi hedeflenmektedir.

\section{Alt Problemler}

1. DL'nin yetiştirilmesinin öğretmenliğe etkisi nasıldır?

2. DL'nin öğretmenliğe bakış açısı nasıldır?

3. DL'nin köy öğretmenliğine bakış açısı nasıldır?

4. DL 'nin köyde projeler oluşturma yaklaşımı nasıldır?

5. DL ne tür projeler geliştirmiştir ve projelerinin öyküleri nasıldır?

6. DL çalışma sürecini nasıl kontrol etmiştir?

a. Ne tür engellerle karşılaşmıştır?

b. Engelleri nasıl aşmıştır?

c. Çalışmalarını nasıl sistematize etmiştir?

7. Bulgulardan elde edilen hipotezler nelerdir?

$\mathrm{Bu}$ çalışmanın ortaya çıkardığı sonuçları itibariyle, araştırmaya konu edilen bir köy öğretmeninin hangi yollardan geçtiği ve nasıl başardığı diğer benzer durumdaki öğretmenlere yol gösterici özellik taşımaktadır. Diğer yandan araştırma sonuçlarında yer alan bazı zorlukların ortaya çıkarılması ile başarmanın önünde bilinçli veya bilinçsiz bazı kurum ve kişilerin nasıl engel olduğunun farkına varması sağlanabilir. Araştırma sonuçlarının bir başka yararı da ülkemizde benzer durumdaki köy öğretmenlerinin birer köy liderleri olma yolundaki projelerin tasarlanması fikrine 1şık tutacağı yönündedir. 


\section{Yöntem}

Çalışma, nitel araştırma kapsamı içinde yer almaktadır ve durum ça1ışması (case study) ile desenlenmiştir. Durum çalışması, tek bir kişinin, bir ortamın, tek bir tür dokümanın ve olayın ayrıntılı olarak incelenmesidir (Kazak, 2001, s.146). Durum çalışması yaparken temel olarak aşağıdaki basamaklar izlenir (Şimşek ve Yıldırım, 2003, s.194).

Araştırmanın verileri durum çalışmasının konusu olan öğretmen DL ile görüşme yolu ile toplanmıştır. Görüşmede, söylenenlerin yüzeysel anlamları yanında gerçek ve derinliğine anlamları da çıkarılabilir (Türnüklü, 2000; Karasar, 2015). Araştırmada kullanılan görüşme türü yarı yapılandırılmış görüşmedir. Görüşme yarı yapılandırılmış görüşme formu aracılığı ile konuşulanlar kaydedilmek suretiyle gerçekleştirilmiştir.

Veriler betimsel ve sistematik analiz yöntemiyle analiz edilmiştir. Araştırmanın geçerliliği, görüşmelerden elde edilen verilerin basında haber olmuş biçimlerini de birlikte kullanarak gerçekleştirilmesi yoluyla sağlanmıştır. Bir diğer geçerlilik yöntemi, araştırma sonuçlarını araştırmaya konu edilen DL ile paylaşılarak onunla görüş birliğine varılmak suretiyle oluşturulmuştur.

Araştırmanın güvenirliliği ise tüm araştırma süresince izlenen yollar kayıt altına alınarak sağlam bir veri tabanı oluşturulmaya çalışılarak sağlanmaya çalışı1mıştır. Bu biçimde aynı araştırmayı yapmak isteyen araştırmacıların benzer sonuçlara ulaşmasının mümkün olacağı düşünülmüştür.

\section{Bulgular ve Yorum}

Aşağıdaki başlıklarda alt soruların yanıtları ve bu yanıtlara ilişkin yorumlar yer almaktadır.

\section{DL’nin Yetiştirilmesinin Öğretmenliğe Etkisi}

DL, Samsun’un Bafra İlçesinde doğup ve orada büyümüştür. Küçük yaştan itibaren köy yaşamı ile ilgili bilgisi ve yaşantısı vardır. Babası esnaf, annesi ev hanımıdır. Çocukluktan beri sorumluluk verilerek yetiştirilmesi onun "lider ruhlu" olarak gelişiminde önemli bir etkene sahiptir. Bu sorumluluklardan bazılarını DL şöyle ifade etmiştir: “... Kardeşlerime bakmam, onları okula hazırlamam, onlara ögretmenlik yapmam hep benim sorumluluğumda idi.”

DL okul yaşamında da sorumluluk almaya devam etmiş, okulda liderlik 
pozisyonunda olan işleri yüklenmiştir:

“... Hep sınıf başkanı oldum. Bu liderlik ve kendi kendime başarma alışkanlığımdan dolayı olacak ki, Bafra gibi bir yerden, 17 yaşında bir kız çocuğu olarak Ankara Gazi Üniversitesi Sınıf Öğretmenliği bölümüne okumaya gittim. Yani çocukluktan itibaren size aşılanan özgüven, "yapabilirsin" yaklaşımı başarmanızda en büyük etken...”

DL, yaşamın gereklerini yerine getirmesi ve üzerine düşebilecek işleri yapması gereken, Anadolu'daki çoğu çocuklar gibi, sorumluluk alması ve iş yükünü hafifletmesi gereken bir durumdadır. Bu zorunluluk sonuç olarak kendi işlerini nasıl başarabileceğini tasarlayan ve bunun sorumluluğunu alan bir birey yaratmada önemli bir etken olarak belirlenebilir. Bu durum, Cüceloğlu'nun (2006) ebeveynlere atfen belirttiği, çocukların kendi yaşamlarının direksiyonuna kendilerinin oturması ve yaşamlarının sorumluluğunun kendilerinde olduğunun bilincine varması gerektiği bilgisiyle tutarlılık göstermektedir.

\section{DL’nin Öğretmenliğe Bakış Açısı}

DL, öğretmeni sadece çocuklara sınıfta bilgi aktaran biri olarak görmediğini belirtmektedir. Ona göre öğretmenlik bir yaşam biçimidir. Bu yaşam tarzı okuldan ayrıldıktan sonra da okul ve öğrencileri için düşünmeyi, fırsatları onların lehine nasıl kullanacağını hesap etmeyi gerektirmektedir. Diğer yandan öğretmenliğin keyifli yanlarının bulunduğunu şu şekilde ifade etmektedir: “... Soruyorlar bana neden öğretmenlik diye. Öğretmenlikte her yeteneğinizi kullanma firsatınız var. Yani işe yaramayan bir özellik diye bir şey yok. Hangi yeteneğiniz varsa onu sonuna kadar kullanabilirsiniz. Bu türden başka bir meslek yok.”. DL, başka bir deyişle de öğretmenliği şu sözlerle açıklamıştır:

“...Çocuklarla ders yaparken dersin gereği doktor mu olmam gerekiyor. Doktor oluveriyorum. Çiftçi mi olmam gerekiyor hemen kollarl slvıyor iyi bir çiftçi oluyorum. Ben oynayınca çocuklar da çok büyük keyif altyor ben de... Ders bi şekilde oyuna dönüyor. Oyun olduğu için de keyif alınıyor. Üstelik öğretmeye çalıştı̆̆ım konular kalıcı oluyor, daha sonraları konuşuluyor, hatırlanıyor. Monoton bir biçimde sadece derslere gir-çık ve bilgiyi aktar, bu olmamalı. Bu süreçten nasıl keyif alırım, nasıl keyif veririm? Bir ögretmenin kafasında bu soru olmalı..."

Öte yandan DL, her meslekte olduğu gibi öğretmenlikte de zorlukların bulunduğunu, bu zorlukları mesleğin zevk alınabilecek yanlarını bulup onları yaşamakla aşılacağını ya değilse zorluklar içinde kaybolma riski ile karşı karşıya kalınacağını belirtmektedir. 
DL'nin mesleğindeki başarısının ve fark yaratacak işlere imza atmasının temel nedeni öğretmenliği kendisine keyif verecek ve paydaşlarının da keyif alacağı biçimde olayları kurgulamasına yönelik bakış açısıyla ele alması olabilir. Bu süreçten alınan geri bildirimin iş yapmadaki motivasyonu olumlu yönde etkilemesi de beklenen bir durumdur. Bir diğer açıdan işin nasıl yapılacağının birileri tarafından tarif edilmemesi ve kişinin işi kendi işi gibi görmesi ve tasarlaması durumu başarının diğer bir kaynağı olarak yorumlanabilir.

\section{DL’nin Köy Öğretmenliğine Bakış Açısı}

DL, ders verme açısından bakıldığında, öğretmenliğin köy-şehir ayrımının olamayacağını söylüyor. Ancak ders verme dışında köyde öğretmenin farklı sorumlulukları olduğunu belirtiyor. Bu sorumlulukları, okulun fiziksel olarak bakımı ve köyün ve köylünün sorunları ile ilgilenme olarak belirliyor. Bu düşüncesini “... Köyde ögretmenlik çocuklarla çocuk olma, köylüyle köylü olma, o şartlara en iyi uyumu gösterme mesleğidir.” biçiminde özetliyor. Köyde öğretmenlik yapmanın önemini ise aşağıdaki cümleleriyle vurguluyor:

"Başta okulun her şeyisiniz. Okulun bakımı, onarımı, araç gereç temini gibi her şey sizden bekleniyor. Diğer yandan köylü ile içe içe bir yaşamını olmak durumunda. Onların dertleri ile dertleniyor, sevinçleriyle seviniyorsunuz. Bu durumda köyde olup biten her şeye duyarlı olmak durumundasinız."

DL, köydeki çalışmaları yaparken de yukarıda bahsedilen temel ilkesini bir kez daha yineliyor. “... Okulu tamir edeceksem bu bana nasil keyif verir hâle gelir, köylünün bir derdi ile ilgileneceksem bundan hem ben hem köylü nasıl mutlu olur?". DL, köyde öğretmenliğin daha kolay olduğu görüşünde. Nedeni ise yaratıcılığın ortaya çıkmasında engel oluşturabilecek unsurların olmayış1. “...Her şeyden önce kendi işinizin amirisiniz. Memur da sizsiniz müdür de sizsiniz, kimse size bir şey tarif etmiyor. Yaratıcıllğınızı istediğiniz gibi oluşturabilir kullanabilirsiniz.”. Köyde öğretmenliği bir sorun olarak görme yerine bir firsat olarak görüyor... DL'nin köy öğretmenliğine, dolaylı olarak öğretmenliğe bakış açısı “... Öğretmenlik rahat olma mesleği değildir. Gittiğiniz her yerde daha ne yapabilirim diye, deyim yerindeyse ortalı̆̆ karıştırma, güzellikleri ortaya çıkarma mesleğidir. Hizmet odaklı bir meslektir." ifadelerinde anlam bulmaktadir.

Köyde öğretmenlik yapmanın akademik yönünü ise DL şöyle vurguluyor: 
“... Birleştirilmiş sınıfta dört sınıf bir arada eğitim gördüğü için öğrenci başına düşen zaman az fakat sorumluluklar fazladır. Bu durum ögrencilerin küçük yaşlarda sorumluluk alma, gurup çalışmalarına karşı uyumunu ve liderlik becerilerinin gelişmesine sebep olur. Sinıfta öğretmen olmasa bile büyük sınıflar küçük sınıfları kontrol altında tutup yönlendirebilirler. Ayrıca büyük sınıflarla ders işlerken küçük slnıflarında kulak misafirliği yaptığl ve konulara aşina olduğunu söyleyebilirim. Aynı durum üst sınıfları için değişik biçimde geçerli."

DL, köyde öğretmenliği çocuklarla birlikte karar alma ve uygulama olarak görüyor. Bunun şehirlerdeki okullarda zor olacağını savunuyor.

Köyde öğretmenlik kapsamında belirlenen eğitim-öğretim, okulun bakımı ve işletilmesi ve köyün ve köylünün sorunları ile ilgilenme işleri her şeyden önce DL için kendini gerçekleştirme araçları olarak yorumlanabilir. Kendini gerçekleştirme, içsel motivasyon ile çalışmak anlamına gelir. $\mathrm{Bu}$ süreç yapılan işlerden haz duymayla sonuçlanır.

\section{DL’nin Köyde Projeler Oluşturma Yaklaşımı}

DL'nin sorunlara çözüm bulma biçimi önce onlardan rahatsız olma ve daha sonra bunun çözümü için neler yapılması gerektiğini belirleme biçiminde olmaktadır. Çözüm için düşündüğü yöntem genellikle dışardan yardımlar alma yoluyla gerçekleşiyor. “... Bulduğum sponsorlara durumu iyice anlatınca genellikle ikna oluyorlar. Tabi kadın olmamın da etkisi var. Daha anlayışl ve nazik bir biçimde karşılanıyorum.”. Böylece sorunların çözülmeye başlama aşaması gerçekleşiyor. Çözüm sürecinde bir adımı diğer bir adım izliyor ve böylece sona geliniyor. DL sorun çözülünce yapılan işin adını koyarak bunu proje olarak sunuyor. Bir diğer özellik ise işin başından sonuna fotoğraflarını çekiyor ve işin aşamalarını fotoğraflarla gösteriyor. DL için bu bir çeşit kayıt sistemi durumunu oluşturuyor. Böylece nereden başlanıp nereye gelindiği görsel olarak belirlenmiş oluyor.

Proje yaklaşımının temelini düşün-eylem-düşün döngüsünün oluşturduğu düşünülürse DL'nin böyle bir yaklaşımının söz konusu olmadığı görülebilir. Diğer deyişle bir sorunun çözümü için öncesinde her bir ayrıntının tek tek hesap edilmediği, yazılıp çizilmediği söylenebilir. Sorunları ele alma ve çözme mantığı daha çok eylem-düşün-eylem döngüsünde görülmektedir. Bu yaklaşım kriz yönetimlerinde geçerli bir yaklaşımdır. Bu sonuçtan da DL'nin daha çok sorunları kriz olarak ele aldığı, krizi yönetmek yoluyla sorunları çözdüğü ve bütün süreci fotoğraflayarak belgelediği söylenebilir. 


\section{DL’nin Gerçekleştirdiği Projeler ve Öyküleri}

DL gerçekleştirdiği projeleri “Okulum Gençleşiyor, Millî Bayram Kutlamaları ile Halkın Okula Çekilmesi, Biz Her Yerdeyiz, Köy Okulunda Akademik Başarı, Çorba Günü, Bin Bir Kitaplı Kütüphane, Kadın ve Yaşam, Köyde Opera, Öğretmenimin Öğretmeni, Bu Dünya Hepimizin, Okul Öncesi Çocukları Öğreniyor" başlıkları ile ifade etmiştir.

\section{Okulum Gençleşiyor}

DL'nin ilk çalışması olarak nitelendirdiği ve yaptıklarına "Okulum Gençleşiyor" adını verdiği çalışması için söze şöyle başladı "Hocam, aslan

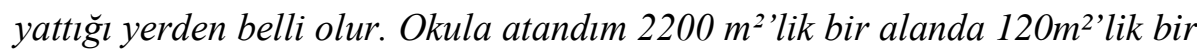
okul, okul demeye bin şahit ister... ne Atatürk büstü var, ne çevre duvarı var, bayrak direği ĕgri...”. Bulgularda, sorunun bu biçimde rahatsızlık verdiği ve çözüm için ilk işin muhtarlar ve azalarla toplantı düzenleyip neler yapacağının görüşüldüğ̈̈ ve bir eylem planı içerisinde hareket edildiği belirtilmektedir. DL bu başlık altındaki çalışmasında okul çatısının onarıldığını, pencere ve camların değiştirildiğini, okuldaki ısınma biçiminin sobadan klimaya dönüştürüldüğünü, zeminin değiştirildiğini, iç ve dış cephe boyalarının yenilendiğini, sıraların, eğitim araç ve gereçlerin, elektrik sisteminin değiştirildiğini ifade etmektedir. Bunun yanı sıra DL, okul bahçesinin düzenlendiğini, oyun park1 yapıldığını, basketbol, voleybol ve futbol sahalarının oluşturulduğunu, bahçenin uygun bir köşesine piknik masalarının getirtildiğini, okulun kullanılmayan diğer sınıfının etkinlik ve hobi sınıfına dönüştürüldüğünü belirtmektedir. DL bu çalışmaya okulum gençleşiyor projesi demektedir. Bir projenin başı ve sonu olmasının hatırlatılması ve çalışmaların hala devam ediyor olmasının nasıl yorumlandığ 1 sorulduğunda "Okulu yenilemenin zaten bir sonu olamaz. Ben orada kaldığım sürece bu çalışmalar devam edecek.” biçiminde yanıt geliyor. Hatta en son, okula güvenlik kamera sisteminin kurulması, bir trafik pisti oluşturularak trafik kurallarının öğretiminin burada uygulayarak gerçekleştirilmesinin söz konusu olduğu belirtiliyor. Bu yeniliklerin kaynağının nereden bulunduğu sorusuna ise “... En küçük esnaftan en büyük şirket yetkililerine ulaşstım. Sözler aldım, takip edip yardım gelene kadar peşini bırakmadım.” yanıtı geliyor.

DL bu çalışmaları ile okulunun Millî Eğitim Bakanlığı'nın (MEB) Okullar Hayat Olsun Projesine dâhil edildiği, devletten hiçbir yardım almadan bu kadar işin yapılmasıyla basına konu olduğu ve diğer okullara örnek olması açısından önemli bir farkındalık yaratıldığını belirtmektedir. 
DL'nin bu çalışmaları kalite yönetiminin çalışma ilkesi olan planla-uygula-kontrol et-önlem al (PUKO) döngüsü ile eşleştiği söylenebilir.

\section{Millî Bayram Kutlamaları}

DL, bu başlık altındaki çalışmasının amacını milli bayramların etrafında köy halkını bütünleştirmek, onlara milli bir heyecanı yaşatmak, diğer yandan yok olmaya bırakılmış köy okullarının varlığını hissettirmek biçiminde özetliyor. “... Hocam düşünsenize! Köyde okul olmadiğında köy halkının bir 23 Nisan'dan, bir Cumhuriyet Bayramindan haberi olmayacak. Köyde milli bir heyecanı başka nasıl yaşatabilirsiniz ki...”. DL ayrıca Mustafa Kemal Atatürk'ün “Öğretmen her firsatta halka ulaşmalı ve halk öğretmenin yalnız alfabeyi ögretenden ibaret olmadiğını bilmelidir.” sözünü rehber edindiğini belirtiyor. Ayrıca millî bayramları kutlama girişimleri ile okuldaki kürsü ve ses sistemi gibi bazı eksikliklerin de giderildiğini belirtiyor.

Millî bayramları kutlama çabaları esnasında öne çıkan diğer bulguları da özetlemek gerekir. Daha bayram kutlamaların başında köy halkı ile bir işbirliği başlamaktadır. Bu durum onların sürece katılmalarını ve kendi çocuklarının bayram etkinliklerine yönelik heyecan duymalarını sağlamaktadır. Ayrıca kendi ifadesiyle “... Okula ilk geldiğimde adını söylemekten çekinen çocuklar artık kendi oyunlarını yazacak duruma geldiler. Onlara önemli bir günde önemli bir iş yapacakları hissini uyandırmanın eğitim açısından ölçüsü nasıl anlatılabilir ki...” biçiminde olmaktadır. Öğrenci sayısının azlığı, öğrencilerin farklı etkinliklerde farklı biçimlerde rol almalarına neden olmaktadır. İhtiyaç duyulan öğrenci kostümlerinin de alınan kumaşları köy halkı ve öğrencilerle birlikte dikerek oluşturulduğu belirtilmektedir.

DL, köy halkını millî bayramlara kendi hazırladığı davetiyelerle davet ettiğini belirtmektedir. Bunun yanında köy camisinden hoparlörle köyün geneline duyuru yaptırmaktadır. DL, "Bayramlara köylünün katılımını çok önemsemekteyim. Amacım okulda bir mıknatıs etkisi yaratmaktır. Böylece daha sonralar okulun liderliğinde köylülerle birlikte pek çok şeye imza atmamız söz konusu olacaktır. Daha sonraları köylülerle oluşturduğumuz marş korosu bu mantıktan çıkmıştır...” ifadeleriyle millî bayram kutlamaları ile oluşan bir sürece dikkat çekmektedir. Yine bu süreç içerisinde önemli faaliyetler gerçekleştirdiklerini, bunlardan birinin “7'den 77’ye Türk Bayră̆ Yapıyoruz” etkinliği olduğunu söylemektedir.

“... Köydeki 3 yaşındaki çocuktan 90 yaşındaki yaşlısına kadar herkesin katılacağı bir etkinlik tasarladık. Ögrenciler tarafindan kesilen 
bezelye tanesi büyüklüğündeki parçalar köydeki bütün evlere dağıtıldt. Her evdeki her bireyin elleriyle bu paçalar büküldü. Cumhuriyet Bayramı Kutlama Etkinliklerinde tüm köy halkı birleşip binlerce parçayl yapıştırdıktan sonra büyük bir el işlemesi bayrak oluşturuldu. Türkiye'de ilk defa yapılan bu etkinlik, hem basın hem de devlet büyüklerinin övgüsü ile ödüllendirildi.”

Yukarıda anlatılan çalışmaların başarı ile sonuçlanmasının bir nedeni öğretmenin köy halk1 ile kurduğu başarılı iletişimin ve onlara kendini kabul ettirmesinin yanında, köy halkının da aslında bu tip değişikliklere hazır olduğu söylenebilir. Özellikle millî duyguları öne çıkaracak etkinlikler halk olarak önemsenen bir durumdur. Köylüler sonucunun yaralı olduğunu hissettiği ve haz alacakları olaylara kolayca yönlenebilmektedirler; yeter ki sunulabilsin.

\section{Biz Her Yerdeyiz}

DL proje diye nitelendirdiği bu çalışmasında amacının köydeki öğrencilerine gezip görme olanağı bulamadığ1 yerleri imkân dâhilinde sunmak, onların gördükleri karşısında duygularını yaşamalarını sağlamak olduğunu belirtmektedir.

“... Çocuklar Samsun'da yaşadiğ halde çoğu deniz görmemiş, trafikte yürümemiş, sinemadan tiyatroda haberleri yok. Ben ilkokul ögretmeniyim. Illkokul öğretmeni çocuklarına ilkleri yaşatan demektir. Diğer yandan bu bir vicdan meselesi de... Benim iki çocuğum var. Onlara neler yapıyorsam bu çocuklara da aynılarını yapmalıyım diye düşündüm.”

Böylece DL, öğrencileri ile birlikte denizde manzara seyretme, faytona binme, Samsun'daki tüm müzeleri rehber eşliğinde gezme, tiyatroya gitme, Samsun Devlet Opera ve Balesinin gösterilerine gitme, Disney Müzik Festivali'ni ücretsiz izleme, Samsun'un büyük çocuk parklarında oyunlar oynama, teleferiğe binme, hayvanat bahçesini ziyaret etme, AVM'de alış-veriş yapma, bowling oynama, uzay gözlem evini ziyaret etme, at çiftliğinde ata binme, lunapark ve sirke gitme, öğretmenin evinde ağırlanma, kitap fuarına gitme, stadyumda törenleri izleme, buz pateninde kayma çalışmaları yapma, uçakla İstanbul gezisine katılma faaliyetlerini gerçekleştirdiğini belirtmektedir. Ayrıca DL, bu faaliyetlerin sonu gelmediğini ve bunların devam edeceğini söylemektedir.

DL'nin bu çalışmaları, bir meslek aşkı ve özveri ile gerçekleştirilebileceği öncelikle dikkat çeken bir durumdur. Bunun doğrudan öğretmenliğe olan motivasyonla, oluşan veya oluşabilecek her firsatın çocukların yararına 
nasıl dönüşeceğini hesap etmekle ilgisi vardır. Bir öğretim liderinin temel özelliği eğitim firsatlarını başlatma ve yaratma olduğu düşünülürse DL bunu sağlamak için çeşitli yöntemler denemiştir.

\section{Bilgi Yarışmalarına Katılıyoruz}

DL yapmış olduğu çalışmalarından dolayı zaman zaman hem meslektaşları hem de amirleri tarafından eleştiriler de almaktadır. "... Etraftan söylentiler ve eleştiriler duyuyorum. Bu Dilek Öğretmen hep çocukları gezdiriyor, dans ettiriyor, konserler, tiyatrolar, sinemalar, hobiler, resimler yapttrıyor, sergiler açıyor, ya bu kadın ne zaman ders yapıyor?” DL öğrencilerini köy okulları arasında yapılan bilgi yarışmasına sokmayı hedefliyor. Bunun hem bu eleştirilere yanıt olacağını hem de yaptığı çalışmaların akademik başarıyla ilgisi olduğunu, aslında akademik başarının temelinde bu tür ça1ışmaların mutlaka yapılması gerektiğini ortaya koyacağına yönelik bir firsat olacağını düşünüyor. Öğrencileriyle her yıl girdikleri yarışmalarda dereceler alıyor. DL bu durumu şöyle ifade ediyor:

“... Köy okulları arasında yapılan bilgi yarışmalarında üst üste dere-
celer aldı. İkinci olduk, birinci olduk. Onlar gezerek, görerek, yaşa-
yarak, hissederek ve eğlenerek ögrendiler. Mezun ettiğim öğrencilerim
beş slnıf bir arada sobalı bir okuldan gidip sekiz yüz, dokuz yüz kişilik
okullarda okul birincileri oldular. En zor yayınevlerinin yaptığ sl-
navlarda ilçe, il dereceleri aldılar. Bu benim için olduğu gibi onlar
içinde müthiş bir gurur kaynağ oldu. Köy okulunda eğitim almanın
başarıya engel olamayacağını ben ögretmen olarak onlar da örnek
birer ögrenci olarak herkese ispatlamıs oldular...”

\section{Çorba Günü}

DL öğrencilerin beslenme alışkanlığından rahatsız olduğunu belirtiyor.

“... Köy okullarında ne kantin var ne yemekhane. Çocuklar doğal olarak evlerinden yiyecek getiriyorlar. Dikkat ettim ya kuru gldalar geliyor ya da hazır gıdalar. Köy bakkalından alış-veriş yapıllyor. Hiç duyulmamış markaların bisküvileri, çikolataları falan. Bu beni rahatsı etti. Almayın, getirmeyin demekle olmuyor. Yerine ne yapılmasl gerektiğini belirlemek inşa etmek gerekiyor."

DL, bu uygulamayla, öğrencilerinin beslenme alışkanlıklarına müdahale etmeyi, okul iklimini olumlu yönde etkilemeyi ve köydeki annelerin birlik ve dayanışma içinde olmalarına yardım etmeyi sağladığını ifade ediyor. Bu etkinlik için önce annelere bir yazı gönderiyor. Gelen tepkileri ölçüyor ve yapılacak işin yararlarını anlatarak gönüllülüğü sağlıyor. Daha sonra okuldaki mutfağı bulduğu sponsorlarla onartıyor ve araç gereç temin ediyor. Hazırlık- 
lar tamamlanınca köydeki annelere haftanın üç günü için program hazırlıyor ve çorba listeleri veriyor. Bu etkinliğin oluşturduğu sonuçları DL, şöyle ifade ediyor:

“... Öncelikle anneler arasında çok iyi bir dayanışma oluşmuştur. Birbirine uzak duranlar bir etkinlik etrafinda birleşince buzlar çözülmeye başllyor. Hatta 'Hocam keşke daha önce bunu düşünseydin.' dediler. Çocuklar hazır gıdalardan uzaklaştılar. Soğu günlerde sıcak çorba içlerini ısıttı ve de okul bir ev sicaklığına döndü. Daha önce böyle bişey denenmemiş...”

Senge (1991), iyileşmenin veya kötüleşmenin sistem işleyişinde döngüsel bir yapı ve sarmal bir boyutta işlediğini söyler. Bu nedenle yapılan artı veya eksi bir girdi bir başka eksi veya artı bir durumu tetikler. Yukarıda çorba etkinliğinde olduğu gibi köyde yapılan diğer etkinlikler için de her olumlu adımın yeni olumlu ortamların oluşmasında katkılar oluşturduğu biçiminde yorumlanabilir.

\section{Bin Bir Kitap Projesi: 2016’da 2016 Kitap}

DL, bu çalışma ile sadece öğrencilerin değil köylünün de okuma alışkanlığı edinmeleri ve köyde okuma kültürünün oluşmasını sağlamak amacında olduğunu vurguluyor. Bunun sağlanması için okuldaki hobi sınıfının bir köşesini kütüphane yapıyor. DL, yayınevlerinden ve sosyal medyadan kitap bağışı yapmalarını istiyor. “... Bir sürü kitap geldi köye. Gelen kitapların 400'e yakını yetişkinlere yönelikti. Böylece bu çalışmanın adını Binbir Gece Masallarından esinlenerek Binbir Kitap Projesi koydum.” DL, çocuğunu okula getiren anneleri yönlendirme ve daveti üzerine 20 dakika serbest okuma yapmalarını sağlıyor. Böylece kısmen de olsa köylünün okuma yapması sağlanmış oluyor. DL, öğrencilerin kütüphaneyi kullanımı hakkında da şunları söylüyor:

“...Öğrenciler okuyacakları kitapları kendileri seçerler. Öğrencilerin okudukları kitaplar sorumlu bir ögrenci tarafindan kaydedilir. Özet defterleri olușturulur. Öğrenciler serbest etkinlikte okudukları kitaplar hakkında sözlü ve yazılı yorumlarda bulunurlar. Her ay en çok kitap okuyan ve yorumlayan ögrenciler ve anneler ödüllendirilir. İsimler okul panosunda duyurulur. Bin bir kitap hedefiyle başlayan proje 2016 'da 2016 kitap projesine dönüşmüștür. Yll boyunca ylpranan ve eskiyen kitaplar yerine kitap temini yapılip sayı korunur...”

\section{Kadın ve Yaşam}

DL, köyde yaşamakta olan kadınların dramından söz ediyor ve onlar için neler yapılabilir sorusuna cevap arıyor. Kadınları sosyal, kültürel ve 
ekonomik açılardan bir şeyler yapması gerektiğini belirtiyor. Bu çabaların ilkinin köyde okuma yazma bilmeyen kadınlara okuma yazma öğretmek olduğunu belirtiyor. “... Okuma yazma bilmeyen kadınları tespit ettim ve iki yll boyunca okuma ve yazma kurslarl düzenledim. Şu anda okuma yazma bilmeyen kadın yok...” Okuma-yazma etkinliği devam ederken köyde ilkokulu bitirmiş iki velinin dışardan ortaokulu bitirmeleri ve bir kadının cesaretlendirilerek ehliyet alması sağlanır. DL kadınlara desteğin başka neler olabileceğine yöneliyor ve köye bir sosyoloğu davet ederek 0-12 yaş annelerin aile ve iletişim konularında 6 ay boyunca eğitilmelerini sağlıyor. Çalışmaların devamı niteliğinde köye yaşam koçları, aile danışmanları, psikologlar davet edilip ev ziyaretleri ve terapiler gerçekleştiriliyor. Ayrıca DL, diş, diyet ve meme kanseri konusunda seminer vermek üzere köye doktorların geldiğini de belirtiyor.

DL, köyde gerçekleştirdiği sosyal ve kültürel etkinlikleri açıklamaya devam ediyor:

“... (gülerek) Bir akşam bütün köy kadınlarını alıp operaya götürdüm. Bu etkinlik ulusal kanalların ana haber bültenlerinde yer aldı. Kadınlar operaya bayldılar. Akşamın bir vakti köy kadınını evinden alıp operaya götürmeye ikna etmeye ise günler öncesinden başladım. Opera işi tutunca üstüne bir de sinemaya gitmek geldi...”

Niçin böyle bir iş yaptığını yine DL şöyle açıklıyor:

“... Benim annem de bir köy kadını ve biliyorum ki köy kadınlarının sosyalleşebileceği tek müzikli ortam kına gecesi ve düğ̈̈̈nler. Ve hatta bir gün bana bunu bir kadın velim, bu durumu dillendirip, "gelenek ve görenek tamam ama biz çok sıklldık. Köydeki dügünlerde sadece gelin ve damat değişiyor, geriye kalan her şey aynı müzik aynı, dans aynı. Düğ̈̈nün yapıldığ yer bile aynı. Farkl bişeyler yaşamak bizim de hakkımız, ne iyi düsünmüssünüz" diye ifade etti. Ben de köydeki kadinların ilk kez kendileri için bir şeyler yapmalarını istedim. Yanlarında çocukları olmadan, eşleri olmadan yalnız kendileri için bu etkinliklere katılsinlar, mutlu olsunlar istedim..."

DL bu uğraşın kendisine nasıl geri bildirim olarak döndügünü ise şöyle ifade ediyor:

“...Onları önemsediğimi hissettikleri zaman daha çok arkamda olup projelerime daha çok destek oluyorlar. Ben belki çok büyük bir holdingin patronu değilim, bir CEO da değilim ama tek bir çağriyla on beş dakika içinde hiçbir karşıllk gözetmeksizin bütün köy halkinı okulun bahçesine toplayabiliyorum. Bu çok büyük bir güç; ögrretmenliğin gücü, ögretmen öyle güven veriyor ki, doğal liderlik süreciniz başllyor. 
Liderlik; karşındakine üstünlük sağlamak, güç göstergesi yapmak değil, aksine liderlik; karşındakine ne kadar üstün olduğunu hissettirip, kendi içlerindeki gücü açı̆̆a çıkarmalarını sağlamaktır.”

DL kültürel etkinliklerin devam ettiğini bunların içerisinde, 8 Mart Dünya Kadınlar günün okulda kutlanması, bu kutlamaları kadınların şiir okuyup kendi şiirlerini yazmaları biçiminde olması, Samsun Büyükşehir Belediyesi Halk Müziği Sanatçılarının okulda ağırlanması ile "Her Kadına Bir Türkü” etkinliğinin gerçekleştirip Türk Halk Müziği Konserine köy halkının katılımı sağlanması olarak belirtiyor.

\section{Kadına Ekmek}

DL, köy kadınlarının ekonomik yaşamda yer almaları ve kendi ekonomik özgürlüklerin sağlamaları için neler yapılabilir sorusuna yöneliyor.

“...Köyde kadınların işi tarım ve hayvancılık. Daha önceleri buralarda ayakkabı sayacılığı yapılırmış. Ben de neden yine olmasın dedim. IŞSUR ile iletişime geçtim ve bu konuda eğitim verebileceklerini söylediler. Okulun kullanılmayan lojmanlarını atölye haline getirdim. 20 kadın burada eğitim aldı. Eski tahta sıralardan tezgâh bölümü oluşturduk, kırık dökük makinalar tamir edilip tüm imkânsızlıklara rağmen üretime geçtik...”

DL, köy kadınlarının yaptıkları sayaları satmalarıyla bir gelire kavuştuklarını, ilk defa banka kartlarına sahip olduklarını ve kadınların hayatlarına ilişkin motivasyon değişikliğini heyecanla anlatır:

“... Köy kadınının üretimine destek amaçlı birçok firmayla bağlantıya geçtim. Binlerce sipariş alınmasına rağmen makine azlığından büyük siparişleri kabul edemedik. Köy kadınlarının bir de havuz hesabı oldu. Ne kadar çok üretirlerse o kadar da çok paraları olacak ama 20 kadın için atölyede yalnızca 3 makine var..."

Olayın basına yansımasıyla köye ziyaretçilerin gelmesi, yer bulunduğu takdirde 15 makinenim daha köye ulaştırılacağı sözü alınmıştır. Bunun üzerine köy muhtarı kendi arazisinden bir bölümünü bu iş için bağışlamış ve DL, bir elektrik firmasının sponsorluğunda prefabrik bir atölye oluşturmuştur. $\mathrm{Bu}$ arada söz verilen makineler köye ulaştırılmamış ve aksilik yaşanmıştır.

“...Artık köy kadınının istihdamı için yer hazırdır, siparişler hazırdır, ancak söz verilen makinalar ortada yoktur. Söz veren kişiler sanki hiç söz vermemiş gibi davrandılar. Ben de her bulduğum firsatı köye makinelerin gelmesi için kullandım. Çă̆rıldı̆̆ım TV programlarında, konferanslarda, sosyal medyada makine istedim. Böylece makinelere kavuştuk. Bunun devamı niteliğinde ikinci etap meslek edinme kursları açıldı. 45 yaş üzeri kadınlar yapma çiçek-keçe yapmayı öğrendi. Üret- 
tiklerini satmaya başladılar...”

DL ses getiren bu faaliyeti daha da yukarıya götürmeye kararlıdır. Rotary Kulübüyle yazışır. Bu yeni aşamanın adına "Kırsalın Melekleri” der. Böylece Japonya ile bağlantı kurulur ve destek istenir. Ve nihayet amaca ulaşılır. Japonya'dan 46000 \$'lık son teknoloji saya makinaları ve iki yıllık malzeme yardımı köye ulaşır.

“... Bahçe duvarımızın uzunluğundan daha uzun bir tır okula yaklaştı. Köy halkı merakla okulun bahçesine koştular. Tırın etrafinda kalabalık birikti. Ben dâhil herkes şaşkınlık içinde kaldık. Bizi hiç tanımayan, hayatında bizi görmemiş ya da hiç Kumköy'e gelmemiş belki de hiç gelmeyecek insanlar bize yardım ettiler. Bu inanılır gibi değildi. Bu yardıma karşılık sorumluluğumun daha da arttı̆̆ını düşündüm..."

\section{Köyde Opera}

DL, köydeki kültürel yaşamın tekdüzeliğini sorun ediyor. Köy halk1 sadece düğünlerde bir araya geliyor. Burada bir eğlence müziği yapılıyor ve bu müzik de giderek orijinal formunu yitirmiş pek de yerel özellikler taş1mıyor. Köylü pek çok eğlenceyi TV de görüyor. Ancak bir konseri hissetmek, onu canlı izlemek kuşkusuz aynı değil. DL, böyle olmadığ 1 için de köylüde bir önyargının oluştuğunu düşünüyor. “... Daha önce kadınları operaya götürmüşü̈m zaten. Kadınlar operaya gidişlerini dillerinden düşürmediler. Her tarafta anlattılar. Sonrasında bazı gençler, orta yaşlılar bana geldiler. Hocam bizi de götür dediler. Sonra neden olmasın dedim. Tüm köyü operaya götüremeyeceğime göre operayı köye getireyim dedim...”

Samsun Opera ve Balesi Müdürlüğü ile görüşmeler yapılır. Tüm ayrintılar konuşulur.

“... Sanatçıların ulaşımı onlara yapılacak ikram, seyirci sandalyeleri, ses düzeni için gerekli elektronik düzeneği, çevre köylere de duyurunun yapılması, seçilecek eserlerin sunumuna kadar her şey en ince ayrıntısına kadar düşünülür. 'Köyde Opera' projesi Türkiye'de ilk olmuştur. $\ddot{U}$ ç yüz sandalye kapasiteli gösteride tüm sandalyeler dolmuştur, çevre köylerden gelenler ise ayakta, ăgaçların altında gösteriyi izlemişlerdir. Sanatçllar opera tarihini mizahlı ve yerel bir dille öyküleştirip anlatmışlardır. Ayrıca köy halkına jest yapıp yalnızca İtalyanca aryalara yer vermeyip Karadeniz türkülerini opera formatında söylemişlerdir. Konserde köy halkının ve çocukların da sahne performansına katılabildikleri ayrı bölümler oluşturulur. Sanatçıların sıcak ve samimi tavırları halkın takdirini toplamıştır. On beş eserin seslendirildiği ve birebir katılımlarla gerçekleşen sahne performansları, çocukların orkestrayı yönetmesi etkinliği iki saate yakın bir zaman almıştır...” 
DL, etkinliğin sonunda köylünün sanatçılara olan ilgisini ve onları tekrar davet etmelerini, müzikten aldıkları keyfi belirtmelerini etkinliğin amacına ulaştığının göstergesi olarak yorumluyor.

\section{Bu Dünya Hepimizin}

DL köyde yine bir başka sorunla karşılaşıyor:

“...Okulumuzun arka bölümünde bir baraj var ve bir gün baraja çalı̧̧malar yapmak üzere Japon mühendisler gelmiş. Ertesi gün çocukların çok heyecanlı şekilde okula geldiklerini ve 'ögretmenim ögretmenim köye gâvurlar geldi.' dediklerini duyunca bu kaba kelimeleri kullanmanın çocukların suçu olmadı̆̆ını, ailelerden kaynaklandı̆̆ını ve bu duruma yönelik bir şeyler yapmam gerektiğini düşünerek, köy halkı yabanclları öcü gibi görmemeli, hakaretvari konuşmalar yapmamalı ve ögrencilerim de medenî bir şekilde insanları insan olduğu için kabullenmeli, sevmeli fikriyle kollarl sıvadım..."

DL, internetten gerekli araştırmaları yapar, yazışmalarını gerçekleştirir. Köyde yabancı eğitmenlerle "İngilizce Kampı" yapacak, öğrencilerinin ve köylünün yabancılarla bir arada yaşamasını sağlayacak, onların "gâvur" olmadığını gösterecektir.

“... Köye yabancı ve gönüllü eğitmenler getirip köyde İngilizce kamp yapmak istediğimi belirten kusa bir proje metnini, önce aracı kurumlara sonra birkaç sponsora gönderdim. Bizim için başvuru sayfası açıldı. Ve okulumuza farkl kıta ve ülkelerden üç tane yabancı gönüllü eğitmen geldi. Güney Kore, Fransa ve Rusya'dan gelen eğitmenler için köyde konaklama, günlük yaşam ve ders planı yaptım. Her gece farklı bir ailenin evinde kalmalarını, öğrencilerimin yabancı insanlarla iletişim kurarken giriş̧ken ve konuşkan bir tavır sergilemelerini istiyordum..."

Böylece yabancı eğitmenlerin köyde, köylülerin yaşamlarına ortak olarak üç hafta geçirmeleri sağlanır. Kuşkusuz pek çok etkileşim yaşanır, kültürler arası geçişler sağlanır.

“... Ders saatleri dişında köyde yürüyüssler yaptılar, ev ziyaretlerinde ve okul bahçesindeki atölyede çalışan kadınların üretiminde bile onlara yardımcı oldular. Köy halkıyla beden diliyle de olsa çok güzel anlaştılar. Hatta köyde kendine Ingilizce sözlük alan kadınlarımız bile oldu. Üç hafta boyunca köyde kalan yabancı eğitmenlerimiz Türk kültürünü yakından tanımış oldular. Dolma sardılar, hamur açtılar, inek bile sağdılar...”

DL bu ve diğer etkinliklerinde hedeflediklerinin çok ötesinde durumların oluştuğunu ifade etmektedir. Bu da olumlu girdilerin doğal olarak olumlu pek çok dişsallıklarının olacağı varsayımını güçlendirmektedir. 


\section{Oyuncak Kütüphanesi}

DL, okul öncesi çocuklarının okuma yazma bilmediklerinden onların kütüphane kullanma alışkanlıklarının oyuncaklar aracılığı ile kazandırılmasının iyi bir yol olacağını düşünüyor. Bunun için daha önce ana sınıfı olarak kullanıma açtığı öğretmen lojmanının bir bölümünü oyuncak kütüphanesi yapmaya karar veriyor. Ana sınıfı öğrencileri kütüphaneden istediği bir oyuncağı alacak, alınan oyuncak kütüphanelerde olduğu gibi kaydedilerek ödünç verilecek, ertesi gün oyuncak kütüphaneye teslim edilecek. Öğrenciler böylece bir kütüphanenin işleyişini oyuncaklar üzerinden öğrenmiş olacaklar. DL bu çalışmadaki hedeflerini böyle ortaya koyuyor. Oyuncak kütüphanesinin kuruluşunu şöyle anlatıyor:

“... Bir köy okulunda oyuncak kütüphanesi kurmak sanıldiğg kadar kolay değildir. Uygun bir fiziksel ortam ve maddi kaynağın yeterli olmasl gerekir. Öncelikle dolaplar, raflar, köşeler oluşturduk. Oyuncak firmalarl, üniversite toplulukları, sivil toplum kuruluşları ile irtibata geçtim. İstanbul Gençlik Platformu ve Turkcell Genel Müdürlüğ̈̈'nün desteği ile okula yüzlerce oyuncak geldi. Anaokulu ögretmeni ile birlikte farkl kategorilerde olan oyuncaklarl okul öncesi ve ilkokul bölümüne uygun olacak şekilde ayırdık; numaralandırılıp fotoğraflarını çektik. 500'den fazla oyuncak okul kayıtlarına geçti... Oyuncakları emanet alan ögrenciler, onları özenle kullanacaklar, nasll oynadıklarını ve neler hissettiklerini ögretmenlerine ve arkadaşlarına anlatacaklar, böylece onların yaratıcllikları gelişecek ve en önemlisi okula oynama ve öğrenme hevesi ile güdülenmiş olarak gelecekler."

DL yapmış olduğu etkinliğin zaferini böyle ifade ederek anlattı. Bu etkinliğin belki de en önemli göstergesi, okulu çocukların dünyasına göre ele alma gerekliliğinin önemini vurgulamaktır.

\section{DL’nin Çalışma Sürecinde Karşılaştığı Engeller, Engellerle Baş Etme Yöntemleri ve Çalışma Sistematiği}

DL tüm bu çalışmalarını yaparken bazen tahmin ettiği, bazen de etmediği engellerle karşılaştığını ifade etmektedir. Bu engeller, köylülerden, meslektaşlarından, amirlerinden ve aile yaşantısından olmak üzere ayrılabilir.

DL, köylülerden gelen engellerin onlarla işbirliği gerektiren işlerde oluştuğunu ifade ediyor. Söz gelimi kadınlarla yapmış olduğu çalışmalarda daha çok erkeklerin evde ve diğer yerlerdeki işlerin aksayabileceği kayg1sından dolayı kadınlara izin vermeme durumunun ortaya çıkması gibi.

Köylülerden gelen diğer bir engel durumunun kültür çatışmasından 
dolayı olduğu söylenebilir. Kadının erkeğe, erkeğin de kadına olan bakış açısı ve biçilmiş roller, yapılan faaliyetlerin engeli olarak görülebiliyor. Örneğin kadına iş edindirme ile ilgili faaliyette, kadının işinin evine, kocasına ve çocuklarına bakmak olduğu görüşü ve gerekçesi ile zorluk çıkarma durumuna dönüşebiliyor.

DL'nin yaşamış olduğu zorluklara bu açıdan bakıldığında bir diğer durumun köylünün okula bakış açısı ile ilgili olduğu sonucu çıkarılabilir. Okul onların ihtiyaçlarını doğrudan ve de görünür bir biçimde karşılayan bir oluşum değildir. Okulun yararları uzun bir zaman dilimi içerisinde, sonradan görülebilmektedir. $\mathrm{Bu}$ da pragmatik ve doğrusal düşünmeye eğimli olduğu varsayılabilecek bir kitle tarafından okulu acilen kalkındırılması gereken bir yer olmaktan çıkarmaktadır. Köyde kurumsal olarak genellikle iki önemli yerden söz edilir; cami ve okul. Genellikle okullar camiler kadar şanslı değildir. DL, köyün camisinin tüm ihtiyaçları en iyi biçimde karşılandığı halde okulun y1kılmaya terk edildiği gerçeğini ifade ediyor. DL, camilerin köy yaşantısında, köylünün birlik ve beraberliğinde ve ibadet ihtiyacını karşılamada çok önemli olduğunu belirtiyor. Yukarıda da değinildiği gibi ibadet ihtiyacı doğrudan karşılanıp, sonucu hemen oluşan, bir durumdur; yani olay görünürdür. DL, okula olması gereken ilgiyi sağlamak için Cuma namazından sonra camiye gider ve okulun da cami gibi ilgiye ihtiyacı olduğunu, köyün imamının bu konuda kendisini destekleyeceğini ve okula yardım edilmesinin gerekliliğini anlatır.

DL karşılaştı̆ğ zorluklardan bir kısmının da meslektaşlarından geldiğini ifade ediyor. Bunun nedenini başta onların köy öğretmenliği ile ilgili algısına bağlıyor.

“... Köyde ögrretmenlik bir geçiş süreci olarak görünüyor. Illeride rahat bir yerde çalışmak için buraların kahrinın çekilmek zorunda olduğu düşünülüyor. Kim istemez rahatlı̆̆ı... Ama ögretmenlik rahatsızlık mesleğidir. Çevrenizde olup bitenden rahatsız olursanız çözüm üretirsiniz ya değilse sizde sorunların bir parçası olursunuz...”

DL, genellikle köy öğretmenliğinin sorun olduğu düşüncesinin hâkim olduğunu vurguluyor. $\mathrm{Bu}$ nedenle yapılan faaliyetlerinin gereksizliğinin kendisine söylendiği, devletin köylerle ilgili algısının belli olduğu, köylerde okulun pek de istenilmediği yönünde düşüncelerin vurgulandığını belirtiyor. DL, bu durumun moral ve motivasyonu önemli ölçüde engellediğini belirtiyor: 
“... Bana “Hocam ne uğraşıyorsun seneye çocuk sayısı 10’un altına düşecek ve okulun zaten kapanacak." diyorlar. Ben de bunun benim ögretmenlik algım olduğunu, gideceğim yerlerde de bu algımın değişmeyeceğini, önce çocuklara, sonra onların ailelerine ve de okuluma elimden gelen her şeyi yapacağımı söylüyorum. Serviste direnç oluşturan bu tür sohbetlerimiz oluyor...”

DL, yaptığı çalışmaların çoğunun ilçe ve ildeki yöneticilerden destek görmesine rağmen zaman zaman kendisinin de anlam veremediği hem bürokratik hem de kişisel dirençlerle karşılaştığını belirtiyor. “... Yapacă̆ım faaliyetlerde bir amirim izin verirken diğeri risk aldiğımı, bunun doğru olmadığını söylüyor. Ama diyorum bakın sizin de amiriniz olan amirim izin vermiş..." DL, yüksek makamda bulunanların adı bir yerlerde geçmezken kendi adının ve okulunun adının bütün ülkede yer almasının, konuşulmasının, haber edilmesinin zor kabul gördügünü belirtiyor. “... Çünkü şu sözleri duydum. Bizim pek çok alanda başarılarımız var. Neden bunlar haber edilmiyor. TEOG başarımız var örneğin. Hep aynı kişinin ve aynı yerin başarı olarak haber edilmesi diğer yapılanları gölgede bırakıyor...”. DL, üst makamlardan gördüğü direncin en somut hâlini dünyadaki en başarılı 50 öğretmenin çağrıldığı Dubai'deki toplantıya davet edilişine izin almadaki süreçte yaşadığını belirtiyor. Önce davetin doğrudan kendisine yapıldığg için özel bir davet olduğu ve buna izin verilemeyeceği belirtiliyor. “... Elin yabancısı bizdeki kuralları nereden bilsin. Diğer ögretmenler nasıl çağrılmışsa ben de öyle çă̆rılmışım. Malezya'dan, İsrail'den, Afganistan'dan diğer yerlerden gelen ögretmenler sorun yaşamiyorlar, üstelik binlerce dolar desteğiyle gönderiliyorlar, ben THY'den sponsorluk ayarlyyorum, izin olmaz, rapor al, deniyor; daha neler...”. Bu engellerin ortadan kalmasının ne kadar önemli olduğunu vurguluyor DL. Ancak kimseye kızgın olmadığını hatta onların da temkinli davranmak adına direnç oluşturduğunu belirtiyor. Çünkü içinde bulunduğumuz bürokratik düzenin bunu gerektirdiğini belirtiyor.

Bunun bir örgüt kültürü sorunu olduğu söylenebilir. Örgüt kültürünü, bir grup veya sınıftaki insanı öteki grup veya sınıftaki insandan ayıran aklın kolektif planlaması olarak yapılan tanımdan yola çıkarsak (Hofstede, 1991), olaylara ilişkin algı farklılıklarını ortaya koymak kolaylaşabilir. Yöneticinin kendi bulunduğu konumun ve sıfatın önemini sürekli hissettirecek biçimde davranma ve bunun mesajını verme kaygısı, yönetimi, işlerin gelişmeye ve iyileşmeye açık hâle getirme aracı olmaktan çıkarıp ne olursa olsun bulunduğu konumda olmasının önemini ve gerekliliğini hissettirecek bir amaç olmaya dönüştürmektedir. Bu durum Hofstade'in güç mesafesi kavramında 
belirttiği gibi, bu mesafenin yüksek olduğu toplumlarda insanların kendilerine ait yerleri koruma ve statü kaybına uğramamak için bunu göstermeleri bilgisiyle de örtüşmektedir.

DL, karşılaştı̆̆ engellerden birisini de aile yaşamının gerektirdiği sorumluluklardan dolayı olduğunu belirtmektedir. İki çocuğu vardır. Biri henüz 2 yaşında diğeri ise 11 yaşındadır. DL, eşi ve yakın çevresi tarafından, yaptığı çalışmalardan dolayı aile yaşamı ile ilgili sorumluluklarını yerine getiremediği uyarısını alır. Bu durumu zaman zaman espriyle karışı “... Hocam valla eşim beni boşayacak...” ifadesi ile dile getirir.

DL, her ne olursa olsun işin bir dengesinin bulunduğu ve bu dengenin sağlanması hâlinde sorunların yönetilebildiğini anlatmaya çalışmaktadır. Bu durum Covey (1997)'in eylemlerde proaktif olmakla ilgili düşünceleri ile açıklanabilir. Covey, proaktif insanların çabalarının odak noktası olarak "Etki Çemberi" oluşturduklarından söz eder. Yani proaktif insanlar, başarabilecekleri şeylerin üzerinde çalışırlar. Enerjilerinin doğası pozitiftir. Böylece etki çemberleri giderek genişler. Tüm yapılan çalışmalara genel olarak bakıld1ğında ve eylemlerin hareket dizgesi düşünüldügünde DL'nin çalışma sistematiği aşağıdaki gibi ele alınabilir:
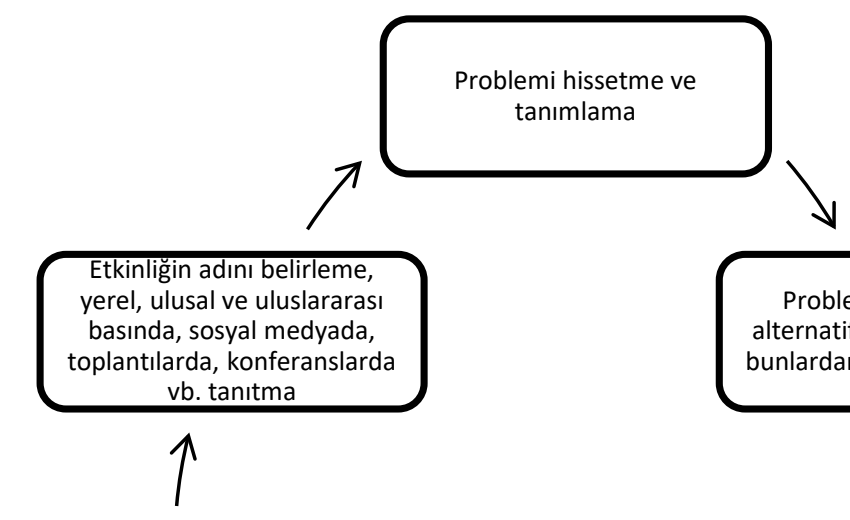

Tanıtım için gereken her türlü veriyi toplama; etkinlikteki tüm yapılanların fotoğrafını çekme
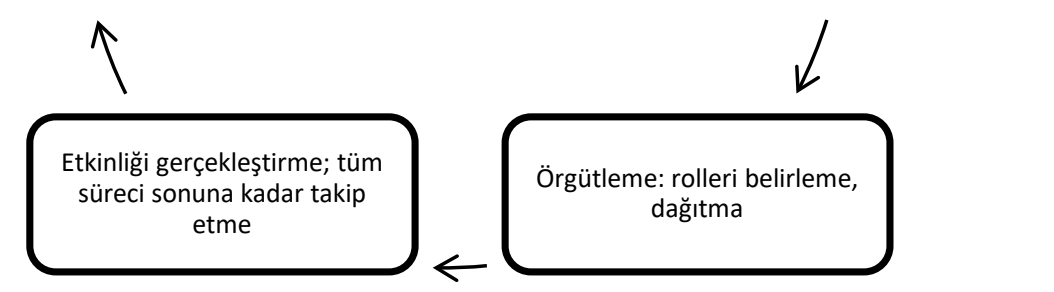

Problemin çözümü için alternatif yollar düşünme ve bunlardan birine karar verme

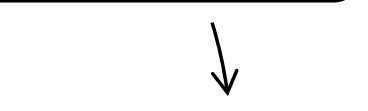

Kaynak arama ve bulma

Kaynak arama ve bulma 


\section{Bulgulardan Elde Edilen Hipotezler}

1. Köyde hayatı ve köylülerle doğru iletişim kurmayı bilen öğretmenler, başarılı olmaktadır.

2. Köy öğretmeni, liderlik becerilerini bilir ve uygularsa başarılı olur.

3. Kişinin iş içinde kendini gerçekleştirmesi, onu başarıya götürmektedir.

4. Sorunları bir kriz olarak ele almak ve yönetip sonuca ulaştırmak, başarılı bir çalışma tarzıdır.

5. Okulda hem çalışana hem de öğrencilere sıkı disiplin uygulamak, yılgınlık ve başarısızlık getirmektedir.

6. Çalışanların takdirini kazanan yöneticiler, iyidir.

7. Öğrencilerin bilişsel başarısı, sosyal, kültürel ve ruhsal etkinliklerle birleştirildiğinde artar.

8. Köy öğretmenliği (köyde lider öğretmenlik), köydeki okulun fiziksel yapısına öğrencilerin akademik, sosyal ve kültürel başarılarına, köyün ve köylünün ekonomik, sosyal ve kültürel boyutlarına sürekli iyileştirmeler yapmak demektir.

\section{Sonuçlar ve Öneriler}

Çalışmanın bulguları doğrultusunda çıkan sonuçlar ve bu sonuçlara dayalı öneriler aşağıda yer almaktadır.

\section{Sonuçlar}

1. DL, küçük yaşlardan itibaren sorumluluk verilerek büyütülmüştür. Bu doğrultuda DL, iş üslenmenin ve üslendiği işi başarıyla sonuçlandırmanın verdiği hazzı küçük yaşlardan beri bilmekte bunu meslek yaşamında da devam ettirmektedir.

2. DL, öğretmenliği keyif alarak yapmaktadır. Mesleğini yürütürken eğlenmekte ve eğlendirmektedir. İşin sahibi konumundadır. Her türlü sorumluluğun kendisinde olduğunu varsaymaktadır.

3. DL'nin öğretmenlik ile bakış açısından hareketle öğretmenlik mesleğinin becerilerinin temelde aynı olduğu, bunun yanısıra köy öğretmenliğinin sorumluluklarının farklılaştığı; köyde okulun fi- 
ziksel yapısı ile ilgili işlerle, köyün ve köylünün gelişimi ile de ilgilenmek gerektiği söylenebilir.

4. Birleştirilmiş sınıflarda eğitim problemi çocukların liderlik özellikleri ve birlikte öğrenme sinerjisi açılarından bir firsat olarak görülebilir.

5. Köyde öğretmenlik düşünüldüğünde hem çocukların eğitimi hem de köye ve köylüye liderlik durumun genel çerçevesidir. Bu çerçevede yapılacak olan iyileişme hareketleri, bir sorunu çözdükten sonra oluşmuş olan yeni durumda yeni bir sorunun ele alınması ile devam etmektedir. Böylece sürekli sorun çözme çabaları ortaya çıkmaktadır. Bu çabalar, DL tarafından proje diye nitelendirilmektedir.

6. Sorun çözme sürecinin her adımı fotoğraflarla, video çekimleriyle belgelenmiştir. Bu belgeleme gerektiğinde sunulmuş böylece aynı zamanda liderliğin de bir gereği olan hem yakın hem de uzak çevrede izleyiciler oluşturmuştur.

7. DL'nin gerçekleştirmiş olduğu çalışmalara bakılarak bir çalışma sistematiği belirlenmiştir. Bu sistematiğin akışı, "problemi hissetme ve tanımlama - problemin çözümü için alternatif yollar düşünme ve bunlardan birine karar verme - kaynak arama ve bulma - örgütleme; rolleri belirleme, dağıtma - etkinliği gerçekleştirme; tüm süreci sonuna kadar takip etme - tanıtım için gereken her türlü veriyi toplama; etkinlikteki tüm yapılanların fotoğrafını çekme - etkinliğin adını belirleme, yerel, ulusal ve uluslararası basında, sosyal medyada, toplantılarda, konferanslarda vb tanıtma" biçiminde belirtilebilir.

\section{Öneriler}

Köyde çalışmakta olan öğretmenlere yönelik bir hizmet içi eğitim programı düzenlenmelidir. Bu programın içeriği köy okulunun fiziksel bakımı ve işletimi, birleştirilmiş sınıf yönetimi ve ders tasarımı, öğrencilerin akademik, sosyal, kültürel başarıları ve bedensel gelişimleri, köye ve köylüye liderlik konularını kapsamalıdır.

Köyde çalışmakta olan öğretmenlerin çabalarını hem tanıma ve takdir etmeye hem de sistemli bir çalışama düzeni sağlamaya yönelik bir model çalışılmalı ve yürürlüğe konulmalıdır. 


\section{Kaynakça}

Aksoy, N. (2008). Birleştirilmiş sınıflarda eğitim-öğretim: Genç ve deneyimsiz öğretmenlerin görüşlerine dayalı bir araştırma. Eğitim Bilim Toplum, 6(21), 83-108.

Aryal, P. N., Neupane, S. R., Laudari, D. C. ve Bhattarai, K. R. (2003). A study on multi-grade/multi-class teaching: Status and issues. Formative Research Project, Tribhuvan University, Research Centre for Educational Innovation and Development, Tripureshwar, Kathmandu, Nepal.

Binbaşığlu, C. (2010). Başlangıçtan günümüze Türk eğitim tarihi. Ankara: An1 Yayınları

Cüceloğlu, D. (2006). Başarıya götüren aile. İstanbul: Remzi Kitabevi.

Covey, S. R. (1997). Etkili insanların yedi alışkanlığı. Kişisel değişim için altın kurallar. (O. Deniztekin, Çev.). İstanbul: Varlık. (Orijinal çalışma basım tarihi 1989)

Drucker, P. F. (2006). The Practice of Management. New York: Collins.

Gedikoğlu, Ş. (1949). Niçin eğitmen kursları, köy enstitüleri. Ankara: İdeal Matbaas1.

Gümüşeli, A. İ. (2014). Eğitim ve öğretim yöntemi. Ankara: Pegem Akademi.

Hargreaves, E., Montreo, C., Chau, N., Sibl1, M. ve Thanh, T. (2001). 4. Multigrade teaching in Peru, Sri Lanka and Vietnam: An overview. International Journal of Educational Development, 21, 499-520.

Hofstede, G. (1991). Cultures and organizations: Software of the mind. London: McGraw-Hill.

Kaplan, M., Oran, H., Metin, M., Güvendi, M. ve Akgöl, H. (1993). Çağdaş eğitim ve köy enstitüleri. İzmir: Dikili Belediyesi Kültür Yayınları.

Karasar, N. (2015). Bilimsel araştırma yöntemi. Ankara: Nobel Yayıncılık.

Kazak, N. (2001). Sosyal bilimlerde araştırma yöntemleri. Eskişehir: Anadolu Üniversitesi Yayınları.

Köksal, K. (2005). Birleştirilmişs sinıflarda ögretim. Ankara: Pegem A Yayıncilik. 
Kültür Bakanlığı. (1940). Köy enstitüleri kanunu. Ankara: Türkiye Büyük Millet Meclisi Matbaas1.

Oğuzkan, A. F. (1981). Eğitim terimleri sözlüğ̈̈̈. Ankara: T.D.K. Yayınları.

Resmi Gazete. (1924). Köy kanunu. Resmi Gazete, 5(68), 336.

Senge, P. (1991). Beşinci disiplin. (A. İldeniz ve A. Doğukan, Çev.). İstanbul: Yapı Kredi Yayınları. (Orijinal çalışma basım tarihi 1993)

Şahin, A. E. (3 Şubat 2016). Birleştirilmiş Sınıflar. Cumhuriyet Gazetesi, 2.

Şahin, Ç. (2007). Birleştirilmişs sınıflarda öğretim. Ankara: Pegem A Yayınc1lık.

Şeren, M. (1982). Türkiye'de köye ögrretmen yetiștirme: Köy enstitüleri sistemi. Yayınlanmamış yüksek lisans tezi, A.Ü. Eğitim Fakültesi.

Şimşek, H. ve Yıldırım, A. (2003). Sosyal bilimlerde nitel araştırma yöntemleri. Ankara: Seçkin.

Taşdemir, M. (2012). Birleştirilmişs sınıflarla öğretim. Ankara: Pegem A Yayınları.

Türk Dil Kurumu. (1980). Toplumbilim terimleri sözlüğü. Ankara: T.D.K. Yayınları.

Türnüklü, A. (2000). Eğitimbilim araştırmalarında etkin olarak kullanılabilecek nitel bir araştırma tekniği: Görüşme. Kuram ve Uygulamada Ĕ̈itim Yönetimi Dergisi, 24(24), 543-559. 